\title{
EFFECT OF EXPORT CREDIT INSURANCE OF TURK EXIMBANK ON EXPORT: A STUDY ON AFRICA
}

\author{
DOI: 10.17261/Pressacademia.2021.1520 \\ PAP- V.14-2021(46)-p.160-162
}

Yasin Baysan ${ }^{1}$, Serkan Cankaya ${ }^{2}$

${ }^{1}$ Istanbul Commerce University, Graduate School of Finance, Financial Economics, Istanbul, Turkey. yasin.baysan@istanbulticaret.edu.tr, ORCID: 0000-0001-6517-6005

${ }^{2}$ Istanbul Commerce University, Faculty of Business, Department of Banking \& Finance, Istanbul, Turkey. scankaya@ticaret.edu.tr, ORCID: 0000-0003-3010-0697

\section{To cite this document}

Baysan, Y., Cankaya, S., (2021). Effect of export credit insurance of Turk Eximbank on export: a study on Africa. PressAcademia Procedia (PAP), 14, 160-162.

Permanent link to this document: http://doi.org/10.17261/Pressacademia.2021.1520

Copyright: Published by PressAcademia and limited licensed re-use rights only.

\section{ABSTRACT}

Purpose- Export credit insurance is an important tool for correcting market failures caused by transaction costs due to asymmetric information, distrust of buyer's quality and collecting export receivables with confidence. By eliminating political and commercial risks, it helps exporters to enter new markets with confidence and increase their sales. This study aims to determine the effect of export credit insurance support of Turk Eximbank on export between the years of 2003 and 2019 which is an important component of Turkey's Africa Strategy.

Methodology- The study employs panel gravity model in which Poisson pseudo maximum likelihood regressor is used. Turkey's exports are included as the dependent variable in the model whereas the independent variables used are export credit insurance, income of importer countries and the distance between importer countries and Turkey. In order to find out the effect of the African Strategy on exports, the dummy variables of free trade agreements, location of Turkish Embassies, Turkish Airlines' flight destinations, the common culture relationship and landlocked are also included in the model.

Findings- The findings indicate that export credit insurance, income of importer country, diplomatic missions and direct flights between countries have positive effect on exports while distance and landlocked have negative effect. In addition, Turkey's Africa Strategy implemented through public diplomacy seems to be successful in increasing exports.

Conclusion- It may be concluded that export credit insurance is important in terms of eliminating uncertainties as well as non-payments, and that region/continent oriented policies increase exports. In this context, it is recommended that exporters who are planning to enter new markets should benefit from export credit insurance support of Turk Eximbank. On the other hand, it is considered that more information can be obtained about buyers and products devoted to buyers can be better promoted by establishing Turk Eximbank liaison offices within diplomatic missions overseas.

Keywords: Turkey's Africa strategy, Turk Eximbank, export credit insurance, gravity model, Poisson Pseudo maximum likelihood JEL Codes: F14, G28, C23

\section{TÜRK EXIMBANK IHRACAT KREDI SIGORTASININ IHRACATA ETKISI: AFRIKA ÜZERINE BÍR ÇALIŞMA}

\section{ÖZET}

Amaç- İhracat kredi sigortası, asimetrik bilgi ve alıcının kalitesine ilişkin güvensizlik nedeniyle işlem maliyetlerinden kaynaklanan piyasa başarısızlıklarını düzeltmek ve ihracat alacaklarını güvenle tahsil etmek için önemli bir araçtır. Politik ve ticari riskleri ortadan kaldırırarak ihracatçıların yeni pazarlara güvenle girmelerine ve satışlarını artırmalarına yardımcı olmaktadır. Bu çalışmada, Türk Eximbank ihracat kredi sigortası desteğinin, Türkiye'nin Afrika Stratejisinin önemli bir bileşeni olan ihracata etkisinin, 2003-2019 dönemi için tespit edilmesi amaçlanmaktadır.

Yöntem- Poisson pseudo en çok olabilirlik tahmincisi kullanılarak panel çekim modeli yardımıyla kurulan modelled kullanılan bağımsız değişkenler ihracat kredi sigortası, ithalatçı ülkelerin gelirleri ve ithalatçı ülkeler ile Türkiye arasındaki uzaklıktır. Afrika Stratejisinin ihracata etkisini belirleyebilmek için serbest ticaret anlaşmaları, T.C. Büyükelçiliklerinin mukim olduğu ülkeler, Türk Hava Yolları A.O.nun uçuş noktaları, ortak kültür ilişkisi ve denize kıyı olma kukla değişkenleri de modele dahil edilmiştir.

Bulgular- Elde edilen bulgular, ihracat kredi sigortası, ithalatçı ülke geliri, diplomatik temsilcilik ve ülkeler arası doğrudan uçuş değişkenlerinin ihracatı olumlu; ülkeler arasındaki uzaklık ve denize kıyı olma değişkenlerinin ise ihracatı olumsuz etkilediğini göstermektedir. Ayrıca, kamu diplomasisi vasıtasıyla uygulanan Afrika Stratejisinin ihracatı artırmada başarılı olduğu görülmektedir. 
Sonuç- Çalışma sonuçları, belirsizliklerin giderilmesi ve batık riskinin bertaraf edilmesi açısından ihracat kredi sigortasının önemli olduğunu ve bölge/kıta odaklı politikaların ihracatı artırdığını ortaya koymuştur. Bu çerçevede, özellikle yeni pazarlara yönelmeyi planlayan ihracatçıların, Türk Eximbank ihracat kredi sigortası desteğinden faydalanması tavsiye edilmektedir. Öte yandan, yurt dışındaki diplomatik temsilcilikler içerisinde Türk Eximbank irtibat ofisleri kurularak hem alıcılar hakkında daha fazla bilgi edinilebileceği hem de alıcılara yönelik olan Türk Eximbank ürünlerinin daha iyi tanıtılabileceği değerlendirilmektedir.

Anahtar Kelimeler: Türkiye'nin Afrika stratejisi, Türk Eximbank, ihracat kredi sigortası, çekim modeli, Poisson Pseudo en çok olabilirlik. JEL Kodları: F14, G28, C23

\section{REFERENCES}

Agarwal, N. \& Z. Wang (2017). Does the US EXIM Bank really promote US exports? The World Economy, 41, $1378-1414$.

Amiti, M. \& D. Weinstein (2009). Exports and financial shocks. The Quarterly Journal of Economics, 126, 1841-1877.

Anderson, J. (1979). A Theoretical Foundation for the Gravity Equation. The American Economic Review, 69(1), $106-116$.

Anderson, J. E. \& Y. V. Yotov (2016). Terms of trade and global efficiency effects of free trade agreements. Journal of International Economics, 99(C), 279-298

Auboin, M. \& M. Engemann (2014). Testing the trade credit and trade link: evidence from data on export credit insurance. Review of World Economics, 150(4), 715-743.

Badinger, H. \& T. Url (2013). Export credit guarantees and export performance: Evidence from Austrian firm-level data. World Economy, 36(9), 1115-1130.

Balcı, S. (2018). Export credit insurance effect on Turkey's export to emerging markets: an empirical analysis. Yayımlanmamış Doktora Tezi, Istanbul Bilgi University/Institute of Social Sciences, Istanbul.

Baldwin, R. \& D. Taglioni (2006). Gravity for dummies and dummies for gravity equations. NBER Working Papers 12516 , National Bureau of Economic Research, Inc.

Baltensperger, E. \& N. Herger (2009). Exporting against risk? Theory and evidence from public export insurance schemes in OECD countries. Open Economies Review, 20(4), 545-563.

Bergstrand, J. H. (1985). The Gravity Equation in International trade: some microeconomic foundations and emipirical evidence. Review of Economics and Statistics, 67(3), 474-481.

Brunner, H. P. (2015). Testing the link between accessible export finance and insurance, and regional trade growth in Africa and Asia: a role for regional export credit and investment guarantee agency (ECIGA). Asian Development Bank Economics Working Paper Series, 433.

Deardorff, A. (1998). Determinants of bilateral trade: does gravity work in a classical world? içinde: The Regionalization of the World Economy, Frankel, J., Ed., University of Chicago Press, Chicago.

Demiroğlu, Ö. (2019). Serbest ticaret anlaşmalarının dış ticarete etkisi: Türkiye için karşılaştırmalı bir analiz. Yayımlanmamış Doktora Tezi, Istanbul Ticaret Üniversitesi, Dış Ticaret Enstitüsü, İstanbul.

Eaton, J. \& S. Kortum (2002). Technology, geography and trade. Econometrica, 70(5), 1741-1779.

Egger, P. \& T. Url (2006). Public export credit guarantees and foreign trade structure: evidence from Austria. The World Economy, 29(4), 399418.

OECD. Export credits work at the OECD. https://www.oecd.org/trade/topics/export-credits/, 31.05.2021.

TXF. Export finance: a guide for importers. https://www.txfnews.com/special/GuideForlmporters, 01.06.2021.

Felbermayr, G. J. \& E. Yalcin (2013). Export credit guarantees and export performance: An empirical analysis for Germany. World Economy, 36(8), 967-999.

Fitzgerald, B. \& T. Monson (1989). Preferential credit and insurance as means to promote exports. The World Bank Research Observer, 4(1), 89-114.

García-Alonso, M., P. Levine \& A. Morga (2004). Export credit guarantees, moral hazard and exports quality. Department of Economics Discussion Paper, No. 04,02, University of Kent, Department of Economics, Canterbury.

Gómez-Herrera, E. (2013). Comparing alternative methods to estimate gravity models of bilateral trade. Empirical Economics, 44(3), 10871111.

Hayakawa, K., H. H. Lee \& D. Park (2014). Do export promotion agencies increase exports? Developing Economies, 52(3), 241-261. 
Heiland, I. \& E. Yalcin (2021). Export market risk and the role of state credit guarantees. International Economics and Economy Policy, 18, 25-72.

Herger, N. \& M. Lobsiger (2010). How do export risk guarantees affect exports? The case of Swizerland. The Swiss Review of International Economic Relations, 65(3), 297-319.

Janda, K., E. Michalikova \& L. Psenakova (2013). The performance of export credit agencies in post- communist Central European countries. Institute of Economic Studies, Working Paper:10/2013.

Kang, K. (2011). Overseas network of export promotion agency and export performance: The Korean case. Contemporary Economic Policy, 29, 274-283.

Kızıltan, A. \& H. Şahin (2020). Çekim modeli uygulanmasında karşılaşılan temel sorunlar ve ampirik çözüm stratejilerine yönelik bir literatür incelemesi. Dumlupınar Üniversitesi Sosyal Bilimler Dergisi, 64, 175-190.

Köksal, C. ve E. Güneren Genç (2019). i̇hracat kredi sigortalarının ihracat değeri üzerindeki etkisi: gelişmiş ülkeler üzerine bir panel veri analizi. Maliye ve Finans Yazıları, 111, 155-170.

Mah, J. S. (2006). The effect of export insurance subsidy on export supply: The experience of Japan. Journal of Asian Economics, 17(4), 646652.

Manova, K., S. Wei \& Z. Zhang (2015). Firm exports and multinational activity under credit constraints. The Review of Economics and Statistics, 97(3), 574-588.

Moser, C., T. Nestmann \& M. Wedow (2008). Political risk and export promotion: Evidence from Germany. The World Economy, 31(6), 781803.

Olivero, M.P. \& Y.V. Yotov (2012). Dynamic gravity: endogenous country size and asset accumulation. Canadian Journal of Economics/Revue canadienne d'économique, 45, 64-92.

Piermartini, R. \& Y. V. Yotov (2016). Estimating trade policy effects with structural gravity. WTO Staff Working Paper, No. ERSD-2016-10, World Trade Organization (WTO), Geneva.

Ravenstein, E. (1885) The laws of migration. Journal of the Statistical Society of London, 48(2), 167-235.

Silva, J. S. \& S. Tenreyro (2006). The log of gravity. The Review of Economics and Statistics, 88(4), 641-658.

Tinbergen, J. (1962). Shaping the world economy:suggestions for an international economic policy. New York:Twentieth Century Fund.

Van der Veer, K. J. M. (2014). The private export credit insurance effect on trade. Journal of Risk and Insurance, 82, 601-624.

Yotov, Y. V., R. Piermartini, J. A. Monteiro \& M. Larch (2016). An advanced guide to trade policy analysis: the structural gravity model. WTO, Geneva/UN, New York.

Yücer, A. (2020). Ticari çekim modelinde çoklu direnç faktörü ve türkiye'nin dış ticaret eğiliminin değerlendirmesi. Dokuz Eylül Üniversitesi Sosyal Bilimler Dergisi, 22(3), 1221-1263. 